\title{
Быстродействующие температурно-стабильные микролазеры
}

\author{
А.Е. Жуков ${ }^{1)}$, Н.В. Крыжановская ${ }^{1)}$, Э.И. Моисеев ${ }^{1)}$, А.М. Можаров ${ }^{1)}$, Ф.И. Зубов ${ }^{1)}$, Н.А. Калюжный ${ }^{2)}$, \\ С.А. Минтаиров ${ }^{2)}$, М.М. Кулагина ${ }^{2)}$, С.А. Блохин ${ }^{2)}$, М.В. Максимов ${ }^{1,2)}$ \\ ${ }^{1}$ Санкт-Петербургский национальный исследовательский Академический университет РАН, \\ Санкт-Петербург, 194021, Хлопина 8(3) \\ ${ }^{2}$ Физико-технический институт им. А.Ф.Иоффе РАН, \\ Санкт-Петербург, 194021, Политехническая, 26 \\ тел:+7 (812) 448-6980, факс:+7 (812)448-6980, эл.nочта: zhukale@ gmail.com
}

DOI 10.34077/RCSP2019-66

Исследованы инжекционные микродисковые лазеры на GaAs и $\mathrm{Si}$ подложках, с активной областью на основе квантовых точек различного типа. Показана возможность работы в непрерывном режиме без термостабилизации при комнатной и повышенных температурах, низкопороговой генерации, прямой модуляции с частотой до 6 ГГц.

Основные результаты:

1. Были созданы микродисковые лазеры диаметром 10-31 мкм на основе гетероструктур с активной областью, представляющей собой квантовые точки (КТ) Странского-Крастанова InAs/InGaAs спектрального диапазона 1.28-1.3 мкм, либо формируемые на слабо-разориентированных подложках плотные массивы островков InGaAs (квантовые ямы-точки, КЯТ) спектрального диапазона около 1.1

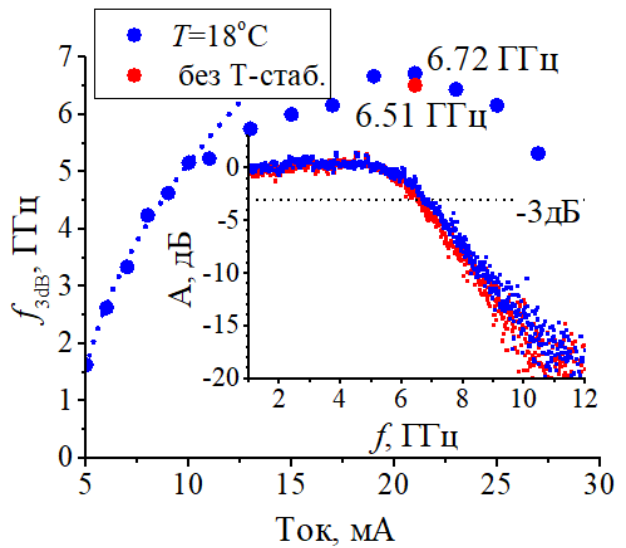

Рис. 1. Зависимость частоты модуляции по уровню -ЗдБ от тока инжекции. Вставка: пример амплитудно-частотной характеристики. Синие символы: $18^{\circ} \mathrm{C}$, красные символы: без температурной стабилизации. $D=23$ мкм. мкм. Структуры были синтезированы на подложках GaAs. Кроме того, были исследованы микролазеры на основе КТ InAs/InGaAs, выращенные на подложках $\mathrm{Si}$ с использованием переходных буферных слоев и дислокационных фильтров.

2. Минимальное значение пороговой плотности тока в микролазерах с KT InAs/InGaAs на GaAs, работающих при комнатной температуре в непрерывном режиме без принудительного охлаждения, составляет $250 \mathrm{~A} / \mathrm{cm}^{2}(\mathrm{D}=31$ мкм), что является рекордно-низким значением для микролазеров на КТ. В микролазерах на $\mathrm{Si}$ подложках такого же диаметра и с таким же типом активной области минимальное значение пороговой плотности тока составило $600 \mathrm{~A} / \mathrm{cm}^{2}$. В микролазерах с активной областью на основе массива КЯТ значительный вклад в порог генерации дает безызлучательная поверхностная рекомбинация, что было приписано меньшей глубине локализации носителей заряда в такой активной области по сравнению с KT InAs/InGaAs; минимальное значение пороговой плотности тока равно $800 \mathrm{~A} / \mathrm{cm}^{2}$.

3. Максимальная рабочая температура лазерной генерации при непрерывной накачке микродисоков на $\mathrm{GaAs}$ составила $100-110^{\circ} \mathrm{C}$ и на $\mathrm{Si} 60^{\circ} \mathrm{C}$, что является рекордным значением для микролазеров соответствующего типа. Удельное тепловое сопротивление в обоих случаях составило около $4 \times 10^{-3}$ ${ }^{\circ} \mathrm{C} \times \mathrm{cm}^{2} / \mathrm{MB}$, что в несколько раз ниже, чем у микролазеров на InP.

Оцененная с помощью малосигнального анализа наибольшая частота прямой модуляции (по уровню -3 дБ) превысила 6 ГГц (Рис. 1). При этом частота $f_{3 \mathrm{~dB}}$ в случае отсутствия температурной стабилизации микролазеров практически не изменяется (6.51 ГГц против 6.72 ГГц) по сравнению со случаем стабилизации микролазера с температурой $18^{\circ} \mathrm{C}$.

4. Впервые исследована временная стабильность микродисковых лазеров. При $60^{\circ} \mathrm{C}$ и постоянном токе накачки снижение выходной мощности происходит с темпом около 0.01\%/час. Это позволяет предварительно оценить срок службы при повышенной температуре не хуже $3.8 \times 10^{3}$ часов.

Таким образом, продемонстрированная к настоящему времени совокупность характеристик микродисковых лазеров с квантовыми точками позволяет ожидать реализацию с их помощью лазерных микроизлучателей для систем оптической передачи данных, в том числе на кремнии, работающих без термостабилизации со скоростями по крайней мере 10 Гб/сек.

Работа выполнялась при поддержке РНФ. 